\title{
京都大学が所蔵するスウェン・ヘディンにかかわる 絵画資料について
}

—1908年に打けるへディンの日本訪問による遺産とその意義—

\section{田中和子}

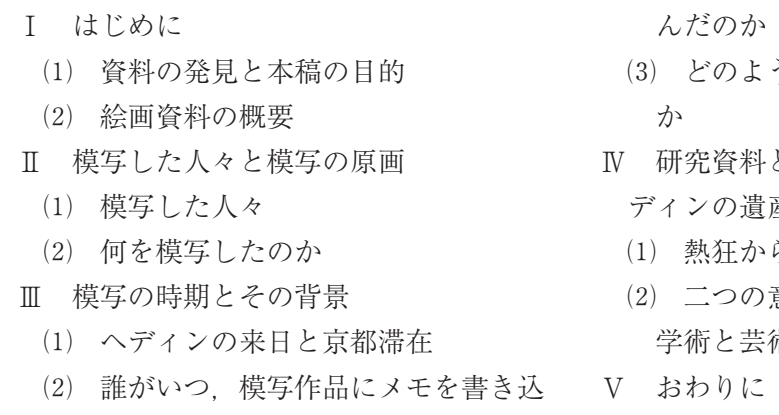

(1) 資料の発見と本稿の目的

(2) 絵画資料の概要

II 模写した人々と模写の原画

(1) 模写した人々

(2) 何を模写したのか

III 模写の時期とその背景

(1) ヘディンの来日と京都滞在

(2) 誰がいつ, 模写作品にメモを書き込 V おわりに

I はじめに

(1)資料の発見と本稿の目的 本稿で紹介する ヘディンにかかわる絵画資料は, ここ数年来, 京 都大学文学部地理学教室で継続してきた所蔵資料 の整理作業のなかで，2014年初頭，キャビネット の引き出しの底から発見されたものである。これ は, 「石田金三西村純二安達伊太郎 模冩 中央アジア (?) 地形・風俗 模䳔 I.」と墨書 きされた厚紙に挟まれていた 26 点と，「中央アジ ア地形風俗 模苞」と墨書きされた封筒に入れ られた 34 点とを合わせた，計 60 点の模写作品であ る。資料には，折れや破損，污れ，日焼け等があ り，保存状態は決して良好ではない。発見された 資料には, どこの何を描いたのか, 模写した人物, 模写された時期，資料が模写されて保管されるに 至る経緯などを記したものは添えられていなかっ
た。

一般的によく用いられる地理学史研究の素材に はさまざまなものがある。たとえば，講義ノート や講演録，日記や書簡，公文書などの文字資料の 他，写真やスケッチなどの画像資料，映画などの 映像資料，会話や独白などの録音資料なども含ま れる。本稿でとりあげる，調査者が描いた原画を 模写した作品という素材は, 従来の研究では主要 な分析対象とはされてこなかったものである。け れども，模写に関わった人々の交流を通して，地 理学および関連科学と芸術の関わりをさまざまな 側面から検討することを可能にする素材である。 本稿の目的は，この新たに発見されたへディンに かかわる絵画資料が，明治期末の地理学を含む学 術や美術の諸分野における国際交流の遺産の一つ であり，同資料が近代学術史および美術史の様相 を解明する上で，貴重な価值を有することを提示 
第 1 表 60 点の模写作品に描かれている対象の分類

Table 1. Classification of contents depicted in the sixty reproduced works.

\begin{tabular}{|c|c|c|c|}
\hline A. 風景 - 屋外景観 & 点数 & 鉛筆／ペン／水彩（点数） & 模写者（点数） \\
\hline \multirow[t]{2}{*}{ (1) 山岳 } & \multirow[t]{2}{*}{5} & ペン(1) & 石田金三(1) \\
\hline & & 水彩(4) & $\begin{array}{l}\text { 石田金三 }(2) \\
\text { 西川純二(2) }\end{array}$ \\
\hline \multirow[t]{2}{*}{ (2) 廃墟群 } & \multirow[t]{2}{*}{4} & 鉛筆(2) & 安達伊太郎(2) \\
\hline & & ペン $(2)$ & 西川純二(2) \\
\hline (3) 廃墟の一部 & 2 & 鉛筆(2) & $\begin{array}{l}\text { 安達伊太郎(1) } \\
\text { 西川純二(1) }\end{array}$ \\
\hline \multirow[t]{2}{*}{ (4) 建物群（寺院） } & \multirow[t]{2}{*}{2} & 鉛筆(1) & 安達伊太郎(1) \\
\hline & & ペンと水彩(1) & 西川純二(1) \\
\hline (5) 建物と群衆 & 1 & 水彩(1) & 安達伊太郎(1) \\
\hline (6) 寺院正面 & 2 & 鉛筆(2) & $\begin{array}{l}\text { 安達伊太郎(1) } \\
\text { 西川純二(1) }\end{array}$ \\
\hline B. 屋内（寺院内部） & 点数 & 鉛筆／ペン／水彩（点数） & 模写者（点数） \\
\hline \multirow[t]{5}{*}{ (1) 祭壇 } & \multirow[t]{5}{*}{6} & 鉛筆と水彩（白黒）(1) & 西川純二(1) \\
\hline & & 鉛筆と水彩(1) & 安達伊太郎(1) \\
\hline & & ペンと水彩(1) & 西川純二(1) \\
\hline & & 鉛筆 $(2)$ & $\begin{array}{l}\text { 西川純二(1) } \\
\text { 田中善之助(1) }\end{array}$ \\
\hline & & ペン(1) & 石田金三(1) \\
\hline \multirow[t]{2}{*}{ (2) 祭壇と僧侶 } & \multirow[t]{2}{*}{2} & 鉛筆と水彩(1) & 石田金三(1) \\
\hline & & 鉛筆(1) & 西川純二(1) \\
\hline (3) 守護神が描かれた入り口の壁面 & 1 & 水彩(1) & 田中善之助(1) \\
\hline (4) 回廊 & 1 & 鉛筆(1) & 西川純二(1) \\
\hline （5）室内（居室） & 1 & 鉛筆と水彩(1) & 西川純二(1) \\
\hline (6) 扉を押す男性 & 1 & 鉛筆と水彩(1) & 西川純二(1) \\
\hline （7）僧侶の集まり & 2 & 鉛筆(2) & $\begin{array}{l}\text { 田中善之助(1) } \\
\text { 安達伊太郎(1) }\end{array}$ \\
\hline C. 人物 & 点数 & 鉛筆／ペン／水彩（点数） & 模写者 (点数) \\
\hline \multirow[t]{3}{*}{ (1)肖像（上半身） } & \multirow[t]{3}{*}{11} & 鉛筆(7) & $\begin{array}{l}\text { 西川純二(3) } \\
\text { 安達伊太郎(2) } \\
\text { 石田金三(1) } \\
\text { 田中善之助(1) }\end{array}$ \\
\hline & & ペン(3) & 西川純二(3) \\
\hline & & 鉛筆と水彩 (白黒) (1) & 安達伊太郎(1) \\
\hline (2) 人物が身につけた装束 & 6 & ペンと水彩(6) & $\begin{array}{l}\text { 西川純二(2) } \\
\text { 安達伊太郎(2) } \\
\text { 石田金三(2) }\end{array}$ \\
\hline \multirow[t]{3}{*}{ (3) 全身像（立ち姿, 装具と衣服) } & \multirow[t]{3}{*}{9} & ペン(7) & 西川純二(7) \\
\hline & & ペンと水彩 $(1)$ & 安達伊太郎(1) \\
\hline & & 水彩 $(1)$ & 安達伊太郎(1) \\
\hline (4) 2 人が並ぶ全身像（装具と衣服） & 2 & ペン(2) & 模写者名記載なし \\
\hline \multirow[t]{2}{*}{ （5）集団（風俗） } & \multirow[t]{2}{*}{2} & 鉛筆(1) & 西川純二(1) \\
\hline & & ペン(1) & 模写者名記載なし \\
\hline
\end{tabular}


することである。以下の章では，まず，発見され た絵画資料がどのようなものであるか, 概要を紹 介する。ついで，現在までの予備的な調査で判明 したことに基づいて, 今後の本格的な調査に向け た仮説と課題を提示する。

(2) 絵画資料の概要 60 点の資料の描画に使わ れていたのは, 鉛筆, ペン, 水彩の 3 種類である。 紙は, 表面がなめらかな薄手のわら半紙と画用紙 で，描くものに合わせて，裁断されたと思われる。 最も小さいもので約 $8 \mathrm{~cm} \times 25 \mathrm{~cm}$, 最大は $21 \mathrm{~cm}$ $\times 63.5 \mathrm{~cm}$ で, 大半は $20 \mathrm{~cm} \times 30 \mathrm{~cm}$ 前後の大きさ である。ペン画にのみ，わら半紙が用いられてい る。

60 点のうち, 57 点の絵の隅には, 「田中善之助 模鷌」という書き方で模写した人の名前が記され ている。模写者は, 西川純二 (30点), 安達伊太 郎 (15点), 石田金三 (8 点), 田中善之助 (4 点) の 4 名である。厚紙の表紙に記載されていた，西 村純二は, 西川純二の誤りであった。

描画の対象は, 風景・屋外の景観, 寺院内部, 人物の 3 つに大別できる。描かれた内容ごとに, 作品の点数, 描画材料, 模写した人を整理したも のが，第 1 表である。人を描いたものが全資料の 半数を占め, 肖像画的なもののほか, 武装した姿 や豪華な装束を身につけた姿が描かれている。ほ かに, 寺院の建物や内部, 修行する僧侶たち, 山 岳風景, 寺院の廃墟などが詳細に描かれている。 寺院や僧侶の特徵は, チベット仏教のものに似て いる。鉛筆画が 22 点, ペン画が16点, ペンや鉛筆 を併用したものも含めて, 水彩画が22点ある。水 彩画のうち 2 点は, 白黒の濃淡のみで描かれてい る。

模写の絵のうち 42 点には, 隅に鉛筆でメモのよ うな単語や語句がアルファベットの筆記体で記載 されている。これらのメモ書きされた鉛筆の線は, 署名の鉛筆や絵に用いられた鉛筆の線とは太さや 濃さが異なる。また，文字は，非常に慣れた書き 方である。文字が不鮮明なものが多いため, 判読
は今後の課題であるが, 一部に, チベットの地名 と推測できる語（たとえば, Mendong や Davaなど) が書かれている。また，人物画に添えたメモ書き に見られる「år」は，スウェーデン語で年齢を表 す語である。

これらの絵画資料の大きな特色は，模写という レベルを超えた，絵そのものの魅力である。模写 の場合，慎重に原画を写そうとするあまり，筆の 勢いが削がれることが多いとされるが，それがま ったくない。人物も寺院も山岳も, 非常に生き生 きと描かれ, 古めかしさは皆無である。

\section{II 模写した人々と模写の原画}

（1）模写した人々 西川純二, 安達伊太郎, 石 田金三, 田中善之助, これら 4 名の名前を地理学 教室創設以来の卒業生名簿と照合したところ, 該 当者はおらず，地理学専攻の学生たちが実習など の際に模写したものではないことが判明した。 そこで，近代美術史の資料を精査したところ， 4 名はいずれも関西美術院に関わる人たちであっ た。関西における本格的な洋画研究と研鑽の中核 的な場であった関西美術院は, 近代洋画の大家で ある浅井忠が中心となって，1906年に京都で設立 された団体である。その前身は，1903年に浅井が 聖護院36番地の自宅内に設立した聖護院洋画研究 所である。浅井忠は，1902年に創設された京都工 芸高等学校 (京都工芸繊維大学の前身) の教授とし て着任し，1907年に亡くなるまで初代院長を務め ている。田中と西川と石田は1906年 3 月の開院か ら翌年 4 月までの間の関西美術院の入学者であり, 安達は 1907 年 5 月から翌年 4 月までの入学者であ る。4 人のうち, 田中（1989-1946）と西川（画家 としての名前は西川純）（1986-1974）と石田は，関 西美術院で開催された競技会でたびたび入選して いる。田中と西川の活動や作品は文献や図録から 確認でき, 二人とも後に, 関西美術院で教授や理 事を務めている。浅井の内弟子として指導を受け た田中は,さまざまな展覧会に精力的に出品する 
かたわら京都画壇における洋画運動を牽引儿, 他 方，鹿子木孟郎の弟子であった西川は，民家の風 景などを描いた個展を頻繁に開催した。安達伊太 郎は, 『顕微鏡及鏡査術式』（1910）に画工として 名前が記されている。

田中や西川ら 4 人が模写を行ったのは，西川純 二が画家として西川純を名乗る前，彼らが画家と して独り立ちする前の修業時代と考えると，20歳 前後の関西美術院入学頃, すなわち1900年代初め 頃と推測できる。

（2 何を模写したのか 第 I 章第 2 節で述べた ように，60点の模写作品に描かれている対象は, 中央アジア，とくにチベットの風景や人々と考え られる。1900年頃に，京都の画学生たちが実際に チベットに出かけてスケッチしたとは考えにくく, 作品には明確に模写と記されている。では, 彼ら は何を見て模写したのであろうか。

20世紀初頭，チベットを写した写真や絵が容易 に入手できる状況ではないし，中央アジアに行っ た人物すら極めて限定される。1900～1902年に日 本人として初めてチベット入りした河口慧海

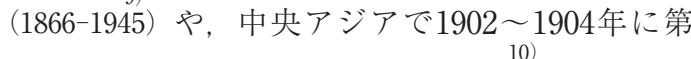
一次探検を行った大谷光瑞（1876-1948）がいるが, ヨーロッパ人では，まず，スウェーデン出身の探 検家スウェン・ヘディン（1865-1952）を挙げるこ とができる。へディンは，1880年代から，何度も 中央アジアを探検し，楼蘭の遺跡を見つけて多く の文物・遺物を入手したほか, ロブノール湖やト ランスーヒマラヤ山系の実態を明らかにし，現地 測量を踏まえた精密な地図を作成するなど，さま ざまな成果を上げた。チベットにも足を踏み入れ ている。彼は絵もたいへんうまく, 多数の著書の 中には，調査中に自ら描いたスケッチや水彩画が 効果的に用いられている。また，第 I 章第 2 節で 指摘したように，年齢を意味するスウェーデン語 「år」が模写図のメモ書きのなかにある。チベッ トと絵画とスウェーデンという 3 つ条件に該当 するのは, ヘディンである。
そこで，ヘディンの中央アジアに関する著作を 調べたところ，Trans-Himalaya（1910-1913）の 3 巻に, 模写作品と同じ内容の絵が数多く掲載さ れていることがわかった。へディンの没後に出版 された素描集であるSven Hedin as artist (1964) の中にも, 模写作品と同じ内容のスケッチが含ま れている。

第 2 表と第 3 表に, 模写作品と Trans-Himala$y a$ (全 3 巻) と素描集に掲載された絵を比較した 一覧を示す。60点のうち35点が Trans-Himalaya に，また，11点が素描集に掲載されている。一覧 表の標識番号は，封筒や厚紙の間で保管されてい た状態での上からの順番に対応している。一例と して，第 1 図に田中善之助による作品（標識番号 II一15）を，また，それに対応するTrans-Himalay $a$ の第 2 巻に掲載されているへディンの絵を 第 2 図に掲げる。第 2 図が印刷を経たものである ことを考慮しなければならないが，2枚の絵は非 常によく似ている。模写作品が，原画の筆遣いた けでなく，描かれた人物の雲囲気まで伝えている ことが見て取れるのではなかろうか。

模写作品とTrans-Himalayaに掲載された挿絵 を比較検討すると，前者が後者を模写したものと は考えにくい。その理由は, 模写作品の中には Trans-Himalaya の挿絵にはない絵があること， 模写作品が非常に精緻に描かれていること,

Trans-Himalaya の挿絵の大きさはわずか数セン チ四方で，これらを元に細密な模写を行うことは きわめて困難であること，白黒図版として掲載さ れた挿絵が模写作品では水彩絵具で鮮やかに描か れていること，挿絵ではカットされている部分ま で描いた模写作品が存在することなどである。

では, ヘディンによるチベットを含む第三回中 央アジア探検（1905-1908年）と，その報告である Trans-Himalaya 出版（1910-1913年）までの間に, 京都の 4 人の画学生たちがへディン自身が探検中 に描いた絵，すなわち原画を実際に見て，模写す る機会はあったのであろうか。 
第2 表 京都大学所蔵の模写作品60点と Trans-himalaya (1910, 1913) およびSven Hedin as artist (1964) に 掲載されたへディンの絵との対照表(1)

Table 2. A conparison table (part 1): the sixty reproduced works stored at Kyoto University and Hedin's illustrations and drawings published in Trans-Himalaya (1910, 1913) and Sven Hedin as artist (1964).

\begin{tabular}{|c|c|c|c|c|c|c|c|}
\hline $\begin{array}{l}\text { 標識番号 } \\
(\text { 表紙をI- } \\
1 \text { 1とする) }\end{array}$ & 模写者 & 描かれたもの & $\begin{array}{l}\text { メモ } \\
\text { 書き }\end{array}$ & $\begin{array}{l}\text { 鉛筆 /ペン / } \\
\text { 水彩 }\end{array}$ & $\begin{array}{l}\text { 縦 } \times \text { 横 } \\
(\mathrm{cm})\end{array}$ & $\begin{array}{l}\text { Trans-Himalaya (1910, } \\
\text { 1913) の挿絵 (巻と挿絵 } \\
\text { 番号) }\end{array}$ & $\begin{array}{l}\text { Sven Hedin as } \\
\text { artist }(1964) \\
\text { の素描番号 }\end{array}$ \\
\hline $\mathrm{I}-2$ & 安達伊太郎 & 地形, 廃墟群 & 有 & 鉛筆 & $25.5 \times 40.9$ & Vol. III, Illustration 95 & - \\
\hline $\mathrm{I}-3$ & 西川純二 & 寺院の建物入り口部分 & 有 & 鉛筆 & $25.5 \times 35.3$ & Vol. I, Illustration 133 & - \\
\hline $\mathrm{I}-4$ & 安達伊太郎 & 寺院の建物正面（額あ & 有 & 鉛筆 & $35.1 \times 25.1$ & Vol. I, Illustration 128 & - \\
\hline $\mathrm{I}-5$ & 安達伊太郎 & 建物群（寺院） & 無 & 鉛筆 & $25.1 \times 35.4$ & Vol. I, Illustration 118 & 110 \\
\hline$I-6$ & 安達伊太郎 & 丘の上の廃墟群 & 有 & 鉛筆 & $25.1 \times 35.8$ & - & 107 \\
\hline $\mathrm{I}-7$ & 西川純二 & 寺院内部の祭壇 & 無 & 全笔+白黒彩 & $35.3 \times 24.8$ & Vol. I, Illustration 125 & - \\
\hline$I-8$ & 安達伊太郎 & 寺院内部の祭壇 & 無 & 鉛筆+水彩 & $25.2 \times 17.5$ & Vol. I, Illustration 129 & - \\
\hline $\mathrm{I}-9$ & 安達伊太郎 & 人物（女性）（上半身） & 無 & 鉛筆 & $35.7 \times 25.6$ & Vol. I, Illustration 158 & 134 \\
\hline $\mathrm{I}-10$ & 西川純二 & 人物（男性）（上半身） & 有 & ペン & $32.3 \times 21.3$ & Vol. II, Illustration 329 & 144 \\
\hline $\mathrm{I}-11$ & 石田金三 & 人物（男性）(上半身) & 有 & 鉛筆 & $34.0 \times 23.3$ & Vol. II, Illustration 327 & - \\
\hline $\mathrm{I}-12$ & 西川純二 & 人物（女性）（上半身） & 有 & 鉛筆 & $33.3 \times 25.3$ & - & - \\
\hline $\mathrm{I}-13$ & 西川純二 & 建物群 (寺院) と山岳 & 有 & ペン＋水彩 & $25.0 \times 35.2$ & - & - \\
\hline $\mathrm{I}-14$ & 西川純二 & $\begin{array}{l}\text { 寺院内部の室内（居 } \\
\text { 室） }\end{array}$ & 有 & 鉛筆＋水彩 & $25.4 \times 40.3$ & - & - \\
\hline $\mathrm{I}-15$ & 西川純二 & 寺院内部（回廊） & 有 & 鉛筆 & $25.0 \times 35.2$ & Vol. I, Illustration 142 & - \\
\hline $\mathrm{I}-16$ & 西川純二 & $\begin{array}{l}\text { 寺院内部の祭壇前, 僧 } \\
\text { 侶 }\end{array}$ & 有 & 鉛筆 & $25.4 \times 40.1$ & - & - \\
\hline $\mathrm{I}-17$ & 西川純二 & 丘の上の廃墟群と山岳 & 有 & ペン & $25.3 \times 40.3$ & $\begin{array}{l}\text { Vol. III, Illustration } \\
\text { 105の右半分 }\end{array}$ & - \\
\hline $\mathrm{I}-18$ & 西川純二 & 寺院内部の祭壇 & 有 & 鉛筆 & $35.2 \times 25.2$ & Vol. I, Illustration 126 & 113 \\
\hline $\mathrm{I}-19$ & 田中善之助 & 寺院内部の祭壇 & 無 & 鉛筆 & $25.1 \times 35.6$ & - & - \\
\hline $\mathrm{I}-20$ & 石田金三 & 祭壇前, 僧侶 & 無 & 鉛筆+水彩 & $25.4 \times 39.8$ & - & - \\
\hline $\mathrm{I}-21$ & 田中善之助 & 寺院内部, 外の景色 & 無 & 水彩 & $25.4 \times 35.2$ & $\begin{array}{l}\text { Vol. III, frontispiece. } \\
\text { (白黒) }\end{array}$ & - \\
\hline $\mathrm{I}-22$ & 西川純二 & $\begin{array}{l}\text { 寺院内部, 屝を押す男 } \\
\text { 性 }\end{array}$ & 無 & 鉛筆＋水彩 & $24.9 \times 35.1$ & Vol. I, Illustration 132 & - \\
\hline $\mathrm{I}-23$ & 田中善之助 & 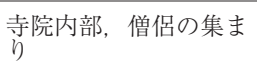 & 無 & 鉛筆 & $25.1 \times 35.2$ & Vol. I, Illustration 154 & 114 \\
\hline $\mathrm{I}-24$ & 西川純二 & 丘の上の廃墟群 & 有 & ペン & $25.6 \times 40.5$ & - & - \\
\hline$I-25$ & 安達伊太郎 & $\begin{array}{l}\text { 寺院内部，僧侶の集ま } \\
\text { り }\end{array}$ & 有 & 鉛筆 & $25.1 \times 35.4$ & Vol. I, Illustration 127 & 115 \\
\hline $\mathrm{I}-26$ & 石田金三 & 寺院内部, 祭壇前 & 有 & ペン & $26.7 \times 38.7$ & $\begin{array}{l}\text { Vol. III, Illustration } \\
111\end{array}$ & - \\
\hline $\mathrm{I}-27$ & 西川純二 & 寺院内部, 祭壇 & $\begin{array}{ll}\text { 無 } \\
\end{array}$ & ペン＋水彩 & $25.2 \times 40.2$ & Vol. II, Illustration 382 & - \\
\hline
\end{tabular}


第 3 表＼cjkstart京都大学所蔵の模写作品60点と Trans-himalaya (1910, 1913）およびSven Hedin as artist (1964) に 掲載されたへディンの絵との対照表(2)

Table 3. A conparison table (part 2): the sixty reproduced works stored at Kyoto University and Hedin's illustrations and drawings published in Trans-Himalaya (1910, 1913) and Sven Hedin as artist (1964).

\begin{tabular}{|c|c|c|c|c|c|c|c|}
\hline $\begin{array}{l}\text { 標識番号 } \\
\text { (封筒をII一 } \\
1 \text { とする) } \\
\end{array}$ & 模写者 & 描かれたもの & $\begin{array}{l}\text { メモ } \\
\text { 書き }\end{array}$ & $\begin{array}{l}\text { 鉛笔/ペン／ } \\
\text { 水彩 }\end{array}$ & $\begin{array}{c}\text { 縦 } \times \text { 横 } \\
(\mathrm{cm})\end{array}$ & $\begin{array}{l}\text { Trans-Himalaya (1910, } \\
\text { 1913) の挿絵 (巻と挿絵 } \\
\text { 番号) }\end{array}$ & $\begin{array}{l}\text { Sven Hedin as } \\
\text { artist (1964) } \\
\text { の素描番号 }\end{array}$ \\
\hline II -2 & 西川純二 & 山岳風景 & 有 & 水彩 & $7.9 \times 25.1$ & - & - \\
\hline $\mathrm{II}-3$ & 石田金三 & 山岳風景 & 有 & ペン & $21.0 \times 63.5$ & Vol. II, Illustration 299 & - \\
\hline $\mathrm{II}-4$ & 石田金三 & 山岳風景, 湖 & 有 & 水彩 & $8.0 \times 25.2$ & - & - \\
\hline $\mathrm{II}-5$ & 西川純二 & 山岳風景 & 有 & 鉛筆＋水彩 & $9.9 \times 25.1$ & - & - \\
\hline II -6 & 石田金三 & 夜の山と月 & 無 & 水彩 & $9.6 \times 25.1$ & - & - \\
\hline $\mathrm{II}-7$ & 安達伊太郎 & $\begin{array}{l}\text { 白と赤の建物と僧侶た } \\
\end{array}$ & 有 & ペン＋水彩 & $9.9 \times 32.3$ & Vol. II, Illustration 360 & - \\
\hline II -8 & 西川純二 & $\begin{array}{l}\text { 建物前にいる } 4 \text { 人（踊 } \\
\text { り? }\end{array}$ & 無 & 鉛筆 & $25.2 \times 17.6$ & 一 & - \\
\hline II -9 & - & $\begin{array}{l}\text { 吊り幕と } 4 \text { 人の人々 } \\
(う 1 \text { 人はキセルで } \\
\text { 煙草を吸う) }\end{array}$ & 無 & ペン & $20.4 \times 25.4$ & - & - \\
\hline II -10 & 安達伊太郎 & $\begin{array}{l}\text { 人物（装束，斜め後ろ } \\
\text { から) }\end{array}$ & 有 & ペン＋水彩 & $25.4 \times 20.3$ & - & - \\
\hline II -11 & 安達伊太郎 & 人物（胸から上） & 有 & $\begin{array}{l}\text { 鉛筆＋白黒彩 } \\
\text { 色 }\end{array}$ & $20.2 \times 12.4$ & - & - \\
\hline$I I-12$ & 西川純二 & $\begin{array}{l}\text { 人物 (装束, 上半身) } \\
\text { (正面) }\end{array}$ & 無 & ペン＋水彩 & $25.4 \times 20.1$ & Vol. II, Illustration 362 & - \\
\hline II -13 & 西川純二 & 人物（装束, 背中） & 有 & ペン＋水彩 & $25.2 \times 20.2$ & Vol. II, Illustration 362 & - \\
\hline $\mathrm{II}-14$ & 安達伊太郎 & $\begin{array}{l}\text { 背物（立ち姿, 武器を } \\
\text { 筫 }\end{array}$ & 無 & ペン＋水彩 & $25.4 \times 20.3$ & - & - \\
\hline II -15 & 田中善之助 & 人物（上半身） & 有 & 鉛筆 & $32.4 \times 21.2$ & Vol. III, Illustration 78 & 135 \\
\hline II -16 & 石田金三 & $\begin{array}{l}\text { 人物（装束，斜め後ろ } \\
\text { から) }\end{array}$ & 有 & $\begin{array}{l}\text { 鉛筆 +ペン + } \\
\text { 水彩 }\end{array}$ & $25.6 \times 20.3$ & Vol. II, Illustration 362 & - \\
\hline II -17 & - & $\begin{array}{l}2 \text { 人の人物 (立ち姿, } \\
1 \text { 人は砂よけ眼鏡) }\end{array}$ & 有 & ペン & $25.5 \times 20.1$ & Vol. II, Illustration 323 & - \\
\hline II -18 & - & $\begin{array}{l}2 \text { 人の人物（立ち姿, } \\
\text { 手に数珠? }\end{array}$ & 有 & ペン & $25.4 \times 20.1$ & - & - \\
\hline II -19 & 西川純二 & $\begin{array}{l}\text { 人物(男性)（立ち姿, } \\
\text { 武器を着) }\end{array}$ & 有 & ペン & $25.5 \times 20.2$ & Vol. II, Illustration 346 & - \\
\hline II -20 & 安達伊太郎 & 人物 (装束, 上半身) & 有 & ペン＋水彩 & $25.4 \times 20.2$ & Vol. II, Illustration 362 & - \\
\hline$I I-21$ & 安達伊太郎 & $\begin{array}{l}\text { 人物 (男性) (横から } \\
\text { の立ち姿, 武器着) }\end{array}$ & 有 & 水彩 & $25.4 \times 20.2$ & Vol. II, Illustration 353 & - \\
\hline$I I-22$ & 石田金三 & $\begin{array}{l}\text { 人物 (装束, 上半身) } \\
\text { (正面) }\end{array}$ & 有 & ペン＋水彩 & $25.6 \times 20.8$ & - & - \\
\hline II -23 & 西川純二 & 人物（胸から上） & 有 & ペン & $25.5 \times 20.2$ & - & - \\
\hline II -24 & 安達伊太郎 & 人物（男性）（上半身） & 有 & 鉛筆 & $32.0 \times 21.3$ & - & 146 \\
\hline$I I-25$ & 西川純二 & $\begin{array}{l}\text { 建物（廃墟）の柱（一 } \\
\text { 部) }\end{array}$ & 無 & 鉛筆 & $27.4 \times 21.3$ & Vol. I, Illustration 33 & 95 \\
\hline II -26 & 西川純二 & $\begin{array}{l}\text { 人物 (男性) (横から } \\
\text { の立ち姿, 武器用) }\end{array}$ & 有 & ペン & $25.4 \times 20.1$ & Vol. II, Illustration 344 & - \\
\hline II -27 & 西川純二 & $\begin{array}{l}\text { 人物 (男性)（正面か } \\
\text { の立姿, 武 } \\
\text { 用) }\end{array}$ & 有 & ペン & $25.3 \times 20.2$ & $\begin{array}{l}\text { Vol. III, Illustration } 63 \\
\text { (three soldiers の中央) }\end{array}$ & - \\
\hline $\mathrm{II}-28$ & 西川純二 & $\begin{array}{l}\text { 人物（横からの立ち } \\
\text { 姿） }\end{array}$ & 有 & ペン & $25.4 \times 20.7$ & - & - \\
\hline II -29 & 安達伊太郎 & 偶像（廃墟の中？） & 無 & 鉛筆 & $25.2 \times 17.6$ & - & - \\
\hline II -30 & 西川純二 & $\begin{array}{l}\text { ヤクに乗った人物（男 } \\
\text { 性, 武器着) }\end{array}$ & 無 & ペン & $20.4 \times 25.2$ & Vol. II, Illustration 348 & - \\
\hline II -31 & 西川純二 & $\begin{array}{l}\text { 人物 (男性) （立ち姿, } \\
\text { 武器着) }\end{array}$ & 有 & ペン & $25.5 \times 20.0$ & - & - \\
\hline II -32 & 西川純二 & 人物（上半身） & 有 & 鉛筆 & $25.2 \times 17.6$ & Vol. III, Illustration 84 & 133 \\
\hline II -33 & 西川純二 & $\begin{array}{l}\text { 人物（正面からの立ち } \\
\text { 姿） }\end{array}$ & 有 & ペン & $25.6 \times 20.0$ & Vol. II, Illustration 324 & - \\
\hline II -34 & 西川純二 & 人物（上半身） & 有 & ペン & $25.3 \times 20.2$ & Vol. II, Illustration 350 & - \\
\hline II -35 & 西川純二 & 人物（上半身） & 有 & 鉛筆 & $25.3 \times 17.4$ & - & - \\
\hline
\end{tabular}




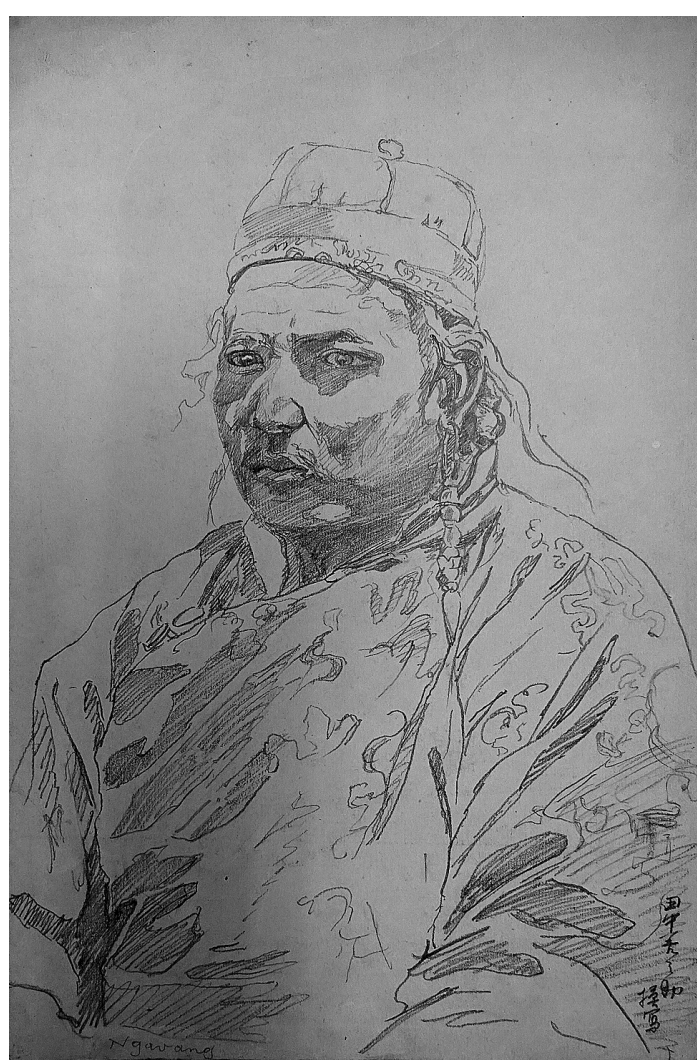

第1図 京都大学で発見されたへディンの絵の模 写作品の 1 つ（標識番号 II-15）（縦 $32.4 \mathrm{~cm}$ $\times$ 横 $21.2 \mathrm{~cm}$ )

Figure 1. A piece of replication work of Hedin's drawing found at Kyoto University: Index Number II-15 $(32.4 \mathrm{~cm} \times 21.2 \mathrm{~cm})$.

\section{III 模写の時期とその背景}

(1)へディンの来日と京都滞在 ヘディンは, 1908年11月から 12 月にかけて約 1 か月間，日本を 訪れ，前半は東京 (横浜), 後半は京都を拠点に 滞在している。同年 8 月, 中央アジア探検を終え た後，インドに逗留していたへディンは，大谷光 瑞の強い勧めに応じて, 東京地学協会の招待を受 けて来日した。長崎到着が 11 月 7 日, 横浜上陸が 同12日であった。へディンの来日に先立ち, 山㠃 直方がへディンの経歴と業績を詳細に取り上げた 講演を行い，学界や世間の関心を高めたほか，東 京地学協会では, 歓迎のために, 山㠃直方, 小川 㻟治，堀賢雄，志賀重昂など21名の担当者を組織

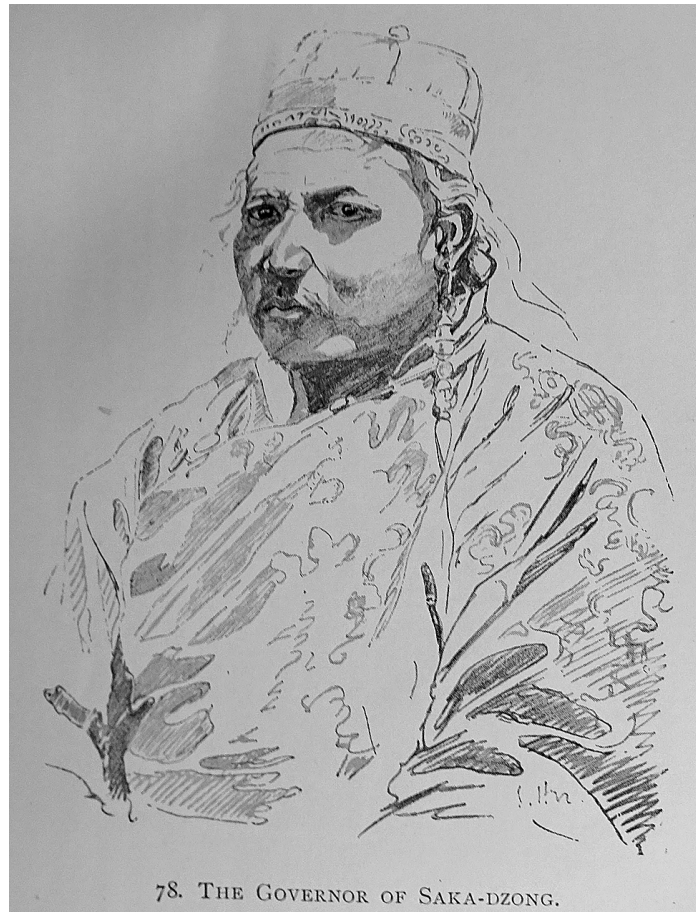

第 2 図 Trans-Himalaya, vol. 2 (1913) に掲載さ れたへディンの絵 : Illustration 78 (縦 $10.5 \mathrm{~cm}$ $\times$ 横 $8 \mathrm{~cm}$ )

Figure 2. Hedin's drawing published in Trans-Himalaya, vol. 2 (1913): Illustration $78(10.5 \mathrm{~cm}$ $\times 8 \mathrm{~cm})$.

し，各方面に寄付を募り，3,912円あまりの歓迎 費用を確保し，連日，盛大な行事を催した。

『地学雑誌』の記録によると, 地図に記されな い空白地帯の踏査に成功したへディンは世界的な 探検家として, 大歓待され, 約30日の滞在中, 官 民の歓迎会だけで60回を超えた。へディンは，滞 在中, 東京と京都でそれぞれ数度の講演会を行い, 明治天皇・皇后に謁見し，勲一等瑞宝章を授与さ れた。11月19日の東京地学協会における講演では, ヘディンは, 中央アジア探検で自ら作成した地図 や多数の実物幻燈写真を用いて, 探検の状態や地 形，風俗，習慣等を詳細に説明した。東京での講 演録は，東京地学協会から『へディン号』という 特集として出版された。この特集には, ヘディン の経歴や講演録（和訳）の他，ヘディンによる地 図（2 葉）やスケッチ（5 葉）も掲載されている。 


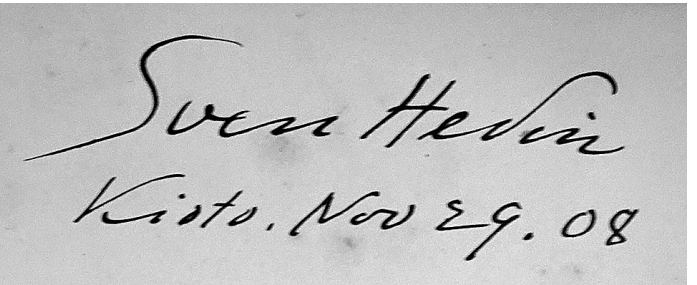

第 3 図 Central Asia and Tibet, vol. 1 (1903) に 記されたへディンの署名（京都大学文学部 地理学教室蔵書)

Figure 3. Hedin's signature on the front page of Central Asia and Tibet, vol. 1 (1903): collection of the Depatment of Geography, Faculty of Letters, Kyoto University.

掲載されたスケッチのうち 2 点は, Trans-Himalaya（1913）の第 2 巻にも Illustration 354および 361 として揭載されている。なお，掲載された地 図は講演で使用されたもので，同協会に保管され ていたが, 関東大震災により失われた。

ヘディンが京都に到着したのは，11月28日夕刻 であった。関西での滞在の中心は, 京都帝国大学 であったが, 大谷光瑞はじめとする本願寺関係者, 京都府，京都市，大阪府，奈良県などの知事や市 長，経済界，新聞通信社などが，こぞって歓迎行 事に加わった。京都帝国大学では，東京地学協会 副会長であった総長菊池大麓，前年に創設された 文科大学地理学教室に着任したばかりの小川环治 (初代教授) ほか, 文科大学の松本文三郎学長, 石 橋五郎, 内藤虎次郎や理工科大学の比企忠などの 教員, 事務官や学生監など, 大学を挙げて, へデ インを学賓として歓待した。ヘディンに大学から の記念品として甲䡒一領と太刀一振が贈られたが, これらのうち甲䡒は，地理学教室が購入したもの である。

ヘディンの京都到着翌日の 29 日午後, 法科大学 講堂で, 学内はもとより, 第三高等学校や府立中 学校, 高等女学校, 京都高等工芸学校, 師範学校 などから聴衆（約1,200名）を集めて，大講演会が 開催された。この講演会に合わせて, 文科大学地 理学研究室別室では，(1)ヘディンの第一回及第二 回探検にかかわる著書（7点），(2)ヘディン自身
による稿図（第三回探検西蔵山岳, 湖沼, 寺院, 人物, 見取図108葉)，(3)中央亜細亜及西蔵探検報告 （1853年から1907までに出版された洋書22点），(4)漢文 中央亜細亜地誌（初刊本禹貢錐指，水経注，水道提 綱ほか全13点), (5) 漢文西蔵地誌（西蔵記ほか 9 点), (6)漢文西域仏典附西藏文仏典（15点），(7)欧訳西 域仏典（4 点），(8)金石（碑㧍よび古鏡など全 4 点）, (9)古図（混一疆理歴代国都図，本派本願寺より出品） が陳列された。

上記(1)の著書のうち, 地理学教室所蔵の図書 3 点には, 講演当日の日付入りで, ヘディンの署名 が記されている(第 3 図)。

注目されるのは，上記の(2)の稿図108葉である。 現在，京都大学で保管されている60点のスケッチ や水彩などの模写作品は, 地理学研究室で展示さ れたへディン自身による絵を模写したものではな いかという仮説を立てることができる。へディン が神戸から日本を発ったのは，12月12日である。 原画と照らし合わせて模写が行われたとすると, それが可能なのは，11月29日の講演会終了後から 日本出発までの短い期間である。4 人がかりとは いえ， 1 点 1 点の模写に要する時間と労力は相当 なものであり，根を詰めた集中的な作業でなけれ ば行いえなかったであろう。

1908年末という時期は，西川，安達，田中，石 田の 4 人が 20 歳前後の 1900 年代初め頃の模写では ないかという，第II章第 1 節で述べた推測と矛盾 しない。

(2) 誰がいつ, 模写作品にメモを書き込んだの か 模写作品にメモ書きをしたのは誰だろうか。 筆記体の文字は非常に書き慣れた手によるもので あり，刊行された挿絵やスケッチにみられるメモ 書きの文字とよく似ており，スウェーデン語 「år」が使用されている。また，メモ書きの内容 は場所や寺院名や人物などにかかわる情報が含ま れるが，その情報を持っており，書き記すことが できたのは,へディンしかいない。というのは, ヘディンの探検では, 護衛や荷物運搬のために現 
地の人たちが大勢雇われていたが、ヨーロッパか らの同行者はいなかったからである。これらを踏 まえると, ヘディン自身が模写作品にメモ書きし た可能性がある。

ヘデインが描いた絵には, 彼のサインと描いた 年号が入ったものが多いが, 模写作品ではサイン と年号は記されていない。また，Trans-Himalaya (1910-1913) やSven Hedin as artist (1964) に 掲載されたスケッチの一部には，ヘディンの手に よると思われるメモ書きが読みとれるものがある。 文字のかすれや印刷による縮小などのため, 厳密 な判読や比較は難しいが，たとえば, Sven Hedin as artist (1964) の Illustration 144のメモ書 きは模写作品の I一10と, また, Illustration 113 のメモ書きは作品 I一18のそれとよく似ている。 ただし，模写作品にメモを書き込んだ人物がへデ インであるとの仮説は，今後，メモその他の筆跡 を厳密に照合する作業を経た上で，改めて検討す る必要がある。

仮に、ヘディンがメモを書いたとしても，メモ 書きができる機会はきわめて限られる。連日の午 餐会と晚餐会, 京都や奈良で寺社や博物館の見学, 大阪で歓迎行事と講話，山県有朋に対する表敬訪 問，大谷一家の手厚いもてなしなど，歓迎行事が 過密なためである。また, メモ書きは, 模写作品 の完成前ではなく，完成したものになされたと考 えるのが妥当であろう。とすると，11月29日の講 演後, 画学生たちが模写作業を始め, 作品ができ あがった後, ヘディンが日本を出発する12月12日 以前までのわずかな期間しか，模写作品にメモを 書き込む機会はない。

なお，模写作品にはメモ書きがあるが，へディ ンの自身の挿絵や素描にはメモ書きがないものが ある。印刷された挿絵や素描には，原画をトリミ ングしたと推測されるものがあるため, 原画にメ モ書きがなかったとは断定できないが，模写作品 にのみ書き込まれたメモがある可能性も否定でき ない。
本稿では，模写作品にメモを書き込みした人物 とその時期については，推論にとどめ, メモ書き の解読などを含めた解明を今後の課題とする。

(3) どのような人物が模写に関わったのか 1908年のヘディンの来日および京都帝国大学来訪, さらに大学講演に際して、へディンが携えてきた 稿眓が展示されたという事実を踏まえると，模写 作品が描かれることになる状況が存在したことは 明らかである。では，自らの原画を模写すること を許したへディンと, 模写した 4 人の画学生たち, さらに模写作品を保管することになった地理学教 室の小川㻟治の間には，どのようなつながりがあ り，どのような経緯で，こうした模写作品が残る ことになったのであろうか。

なによりも, ヘディンの絵を模写するというア イデアを出し, 画学生および彼らの指導者とへデ インとの仲介役をした人物がいたはずである。で きあがった模写作品を，画学生たちがへデインに 直接見せたのか, 仲介者が見せたのか。さらに，

ヘディンのメモ書きを加えた模写図が，なぜ，地 理学教室に保管されることになったのか, 突き止 めるべき事柄は多い。

仲介者がいたとしたら, 絵画, ことに洋画に詳 しく, 模写に值する原画の美術的価值と, 模写す るという行為によって得られる学習効果とを見抜 く能力のある人物である。加えて, 京都帝国大学 の歓迎行事で中心的な役割を果たし，ヘディンと も小川环治とも交渉できる立場の人物であろう。

関西美術院の画学生たちに模写させることに関 与にした可能性があるのは, 関西美術院と京都工 芸高等学校の双方に係わりのある人物である。京 都高等工芸学校は, ヘディンの講演会の案内状が 送付された機関の 1 つであり，同校の校長の中澤 岩太と教授の鹿子木孟郎は，ともに，歓迎行事に 協力している。中澤（関西美術院第二代院長）は菊 池総長とともに, ヘディンの骨董や呉服の買い物 を手伝い, 鹿子木（第三代院長）は，小川㻟治や 石橋五郎らとともに，京都離宮の案内を担当して 
いる。また, 西川純二は, 関西美術院入学前, 鹿 子木の家塾に入門した弟子である。鹿子小や中澤 が, 画学生たちの紹介に関わった可能性が考えら れる。ただ, 関西美術院の院内日誌（1906年 3 月 2 日〜 1911年12月14日）には，この模写作業に関 わる記録はない。簡略な日誌ゆえに省略された可 能性もあるし, 美術院本来の活動とは別のものと して模写が行われた可能性も考えられる。当時の 画学生たちの状況については, 西川純が1908年か ら大阪三越呉服店衣装部に勤務したことや，田中 善之助が1908年に行われた第 2 回文展で入選した ことが明らかである。けれども，同年末に行われ た彼らによる模写作業についての記録は見当たら ない。

関西美術院もその前身の聖護院洋画研究所も, また, 京都工芸高等学校も京都帝国大学とは近い 場所に所在しており，それらに親しく出入りした 人物がいたとしても不自然ではない。上記のよう に，鹿子木と小川琢治との面識はあったにしても， 彼らとへディンに模写の企画を提案し, 了解をと りつけるような㗢きかけのできる人物がいたので はないか。この点の追求や考証も今後の課題の一 つである。

\section{IV 研究資料としての模写作品の価值一へディ ンの遺産とその意義}

（1)熱狂から忘却へ 1908年のヘディン来訪と その滞在期間中の歓迎の様子は, 東京地学協会の 記録や当時の連日の新聞記事に詳しい。11月16日 の東京帝国大学での講演の際, 満員の会場に入場 できなかった人々が大騒動を起こしたり，千枚ほ どの入場券がまたたくまになくなった等の様子が 報道された。また, ヘディンの妹アルマ(Alma Hedin）は, 学生が号泣し帽子を振りながら「万 歳!」と叫んだ様子など, 若い学生たちの感動が 最もへディンを喜ばせたのではないかと回想して いる。東京地学協会の大イベントであったことや 日本を挙げての熱狂ぶりは, 当時の若い世代の
人々にも強い印象を残したようである。たとえば, 大学卒業間もない頃にへディンの講演を聴いた辻 村太郎は，その夜，地質学志望の心を固め，父に 伴われて講演を聴いた10歳の田中薰は，感激のあ まりただぼうっとなって，「この眼で見たという だけで珠玉の如き思出」と語っている。4 歳頃の 貝塚茂樹も, 父, 小川玩治に連れられて京都ホテ ルでヘディンに面会した記憶があるという。

やや奇妙なことに，こうした当時の熱狂や感激 の様子は，現在，ほとんど忘れられている。1988 年から1989年まで日本各地で開催された「スウェ ン・ヘディンと楼蘭王国展」に寄せて，1908年の 来日歓迎行事が回顧され，ヘディンの簡単な日本 滞在記が翻訳紹介されているほか，近年では，近 代の国際政治における中央アジア探検の意味を問 い直す研究が行われている。2012年には大谷探検 隊によるシルクロード探検の展覧会が，また， 2014年には大谷探検隊の活動拠点でもあった二楽 荘をテーマとした展覧会が開催され，大谷家なら びに探検隊とへディンとの交流が紹介された。

けれども, 地理学あるいは地理学史の分野での ヘディン研究は, 全くといってよいほど影を潜め ている。来日の事実すら知られていないと言って もよい。忘却の要因を詳細にさぐることは本稿の 課題を超えているが, ヘディンに対する日本社会 の関心が学術的なものから精神論へと移行したと いう高木の指摘は注目に值する。大正から昭和前 期にかけての時期, ヘディンについて主として語 られたのは，学術的な成果や発見資料の意義では なく, 辺境の地で困難を乗り越える不撓不屈の敢 闘精神であった。学術的な探検家としてよりも, 偉人伝で語られる冒険家という側面が強調されて きたことによる影響は，考慮すべきことの一つで あろう。

( 2 ) 二つの意義一近代への契機ならびに学術と 芸術の邂哌 こうした忘却の背景には, 地球上の 未知の領域を地理学的に探索する必要性自体が消 滅し，探検への興味が薄れたことがあろう。加え 
て，近代における探検から，地理学を含む諸科学 への移行という大きな流れがある。19世紀から 20 世紀初頭にかけて行われた探検では，ほとんど一 人の探検家あるいは一つの探検隊が, 測量学, 地 図学, 地理学, 民族誌, 博物学, 考古学, 文献学 など広範な学問領域にかかわる調査を遂行し，成 功した探検家はまさに英雄であった。しかしなが ら，20世紀の科学は，より体系的で専門分化した ものに移行し, ヘディン的な英雄の出現しにくい 状況となった。

1908年のヘディンの来訪は, 志賀重昂が語って いるように, 近代日本の社会にも学術研究の上で も，画期となりうる大きなできことであり，たい へんな刺激であったと思われる。へディンの来訪 は, 近代日本の本格的な学術研究への移行と確立 の契機として期待され，実際に，学術研究はその 方向に進んでいくことになったが，その結果，へ ディン訪日そのものが忘れられることにもつなが った。

ヘディンの訪日の意義は, 近代日本の学術の進 展への刺激だけではない。へディンの探検の関心 は, 地形測量だけでなく, 自然全体, 社会や文化, 人々やその生業, 文献や文物などに広く向けられ ていた。また，観察や体験を文字や数字だけでな く，写真や自らの絵で克明に記録した。こうした ヘディンの幅広さは, さまざまな分野の学術・芸 術との交流を生み出す素地であり, 多くの領域の 人々との知的な交流を促すものであった。へディ ンと河口慧海や大谷光瑞との交流は1908年以前か ら行われていたし，へディンの京都滞在中に小川 㻟治が彼のために英訳した『水道提綱』の内容は, ヘディンの中央アジア探検の学術報告にそのまま 掲載されている。こうした観点から考えると, 京 都大学に所蔵されることになった, ヘディンが描 いた原画からの模写もまた, ヘディンの京都滞在 がもたらした学術と芸術との多様な邂逅の産物の 一つととらえることができよう。

ヘディンの絵画をもとにした模写作品は, 近代
日本の学術・芸術の展開の諸相を探る上で, これ までの研究ではとり上げられなかった側面を明ら かにすることのできる貴重な研究資料と評価でき る。

\section{V おわりに}

本稿では, 京都大学文学部地理学教室の所蔵資 料のなかから新たに発見されたへディンの中央ア ジア探検（1905-1908）の際に描かれた絵画の模写 作品60点をとりあげ，それらの概要と予備調査の 結果を紹介した。へディンは，探検を終えてスウ エーデンへの帰国の途に就く直前の1908年末に来 日し，京都に滞在していた。模写作品は，このへ ディンの京都滞在中に, ヘディン自身が描いた原 画から模写されたものである可能性が高いことを 明らかにした。模写した 4 人は, 京都で設立され た関西美術院の一期生と二期生の画学生たちであ つた。

20 世紀初め, 著名な探検家へディンが日本を訪 れたことは，明治期末の日本の地理学界はもとよ り日本中の熱狂的な関心を集めた華やかな出来事 でありながら，現在はほとんど忘れられている。 本稿で紹介した新発見の資料は, このへディンの 来訪に関わる物的な証拠である。この絵画資料が 作成され保存されるに至った経緯や背景を明らか にすることは, 地理学や人文学や芸術の諸領域が 深くかかわりあいながら展開した，近代日本にお ける国際的な学術交流の様相, ならびに, ヘディ ンの来訪が学術や芸術に与えた影響を解明すると いう意義を有する。また, 60点の模写作品は, 日 本における洋画の画法修得と研鑽の具体例である ことや，描かれた内容の学術的な精密さという点 でも検討に值する。チベットに関する学術資料は, 1 世紀前も今日も, 入手は容易ではない。へディ ンの目を通して描かれたチベットの自然と社会と 文化と今日のチベットとを比較検討し, 併せて中 国の古文献におけるチベット記載とへディンの記 載とを照合するという作業は，チベット地域研究 
にとっても，異文化記述における意識変化を探る

上でも重要な課題である。

今後は, 本稿で提示した仮説や課題について,

関連分野の研究者と共同して調査を継続し, ヘデ インが京都に残した絵画の模写という新たな資料 をもとに, 近代の学術と芸術の関わり合いと変化, ならびに，チベット地域の変容を探ることとした w。

[謝辞］調査には, 多くの方々から貴重な助言と教示 をいただいた：平野重光先生（元京都市立美術館学芸 課長, 元倉敷芸術科学大学教授), 栗原知枝先生 (京 都嵯峨芸術大学, 専門講師), 池田巧先生（京都大学 人文科学研究所, 教授), 木津祐子先生（京都大学大 学院文学研究科, 教授), 水野一晴先生 (京都大学大 学院アジア・アフリカ地域研究研究科, 准教授), 服 部勇先生（福井大学名誉教授）。とりわけ，平野先生 には, 模写作品についての美術的な評価や近代京都の 洋画界の状況について懇切丁寧に教えていたたいた。 記して厚く御礼申し上げます。

(京都大学大学院文学研究科)

注

1）石濱裕美子著・永橋和雄写真『図説チベット歴史紀 行』河出書房新社, 1999。

2）模写にかかわった画学生たちの画力については，平 野重光氏（元京都市立美術館学芸課長, 元倉敷芸術科 学大学教授）にコメントをいただいた。

3) 京都大学文学部地理学教室編『京都大学文学部地 理学教室百年史』 / 『地理学 京都の百年』補遺』ナ カニシヤ出版，2008，15-31頁。

4）志賀秀孝・清水佐保子企画 - 編集『浅井忠と関西美 術院展』府中市美術館・京都市美術館・京都新聞社, 2006，195-196頁の「関西美術院入学者名簿」による。

5）志賀秀孝「もうひとつの摇籃一明治洋画と京都・関 西美術院」(前掲 4), 14-18頁。

6）前掲 4）213-215頁。

7）(1)島田康寞『明治の洋画一浅井忠と京都洋画壇』 （日本の美術，353），至文堂，1995，(2)黑田重太郎 『改訂版 京都洋画の黎明期』山㠃書店, 2006（初版 は1947年発行)，(3)前掲 4)，100-103頁に田中善之助 の作品, 114-117頁に西川純の作品が掲載されている。 (4)星野桂三・星野万美子編『生誕101年 田中善之助 展 図録』星野画廊，1990。

8）鈴木文太郎『亚微鏡及鏡査術式』丸善，1910，2 頁。 同書には, 安達伊太郎の描いた顕微鏡㧍よび部品の細 密画が多数掲載されている。

9） 河口慧海著/長沢和俊編『チベット旅行記』(西域 探検紀行全集 7 ) 白水社，1967（原著は，河口慧海
『西藏旅行記 (上巻·下卷)』博文館, 1904)。

10）白須淨眞編『大谷光瑞とスヴェン・ヘディン』勉誠 出版, 2014。

11）（1)ヘディン（山口四郎訳）『探検家としてのわが生 涯』(ヘディン中央アジア探検紀行全集11) 白水社, 1966，(2)金子民雄監修『スウェン・ヘディンと楼蘭王 国展』日本対外文化協会，1988。

12) Hedin, S., Trans-Himalaya: discoveries and adventures in Tibet. (vols. 1-3), Macmillan, 1910, 1913. (初版1909-1912).

13) Hedin, S. (revised and with supplement by Montell, G., and essay by Holmér, F.) (translated by Burton, D.), Sven Hedin as artist for the centenary of Sven Hedin's birth. (Sven Hedin, life and letters: 2) Stockholm: States etnografiska Museum, 1964.

14）金子民雄『ヘディン伝一偉大な探検家の生涯』人物 往来社, 1972。

15）山崎直方「将に来らむとする大探検家，スアン，フ オン，ヘディン氏（明治41年10月20日東京地学協会例 会に於ける講演)」地学雑誌20-11，1908，757-785頁。

16）（1)東京地学協会「スエンヘディン氏招待概記」地学 雑誌20-12，1908，865-868頁，(2)東京地学協会「ス卫 ンヘデイン氏歓迎報告」地学雑誌21-6，1909，a1-a31 頁。

17）（1)東京地学協会「ヘディン博士滞洛記事」地学雑誌 21-6，1909，b1-b12頁，(2)矢澤大二「“スウェン・へ ディンと楼蘭王国展”に想う」地学雑誌98-3，1989, 366-373頁，(3)前掲15）。(4)前掲10）では，「官民挙げ ての対応の異例さ」(13頁）と「大探検家の来日に対 する日本社会の加熱ぶり」(15頁）が指摘されている。 (5)高本康子「ヘディンの来日一近代日本とへデインと チベット」(前掲10)，129頁）に記載された新聞報道 の記事では, 歓迎会の回数は65回。阿部弘敏「アルマ 著“Mein Bruder Sven”が語るへデインの来日」(前 掲10)，321頁）によるへディンの妹アルマの回想では, 69回の祝賀パーティーとある。

18）前掲17）(2)370頁。

19）東京地学協会編纂『ヘディン号』地学論叢 4,1909 , 1-114頁。

20）辻村太郎「スウェン・ヘディンの講演と豆南諸島学 術旅行」地学雑誌 78,1969 ，206頁。

21）（1)京都帝国大学『外国名士招待関係書類（自明治四 十一年至明治四十二年)』京都大学大学文書館所蔵資 料（識別番号：01A19469)，1908-1909，(2)前掲17） (1)。

22）坂口貴弘「スヴェン・ヘディンの京大訪問」京都大 学大学文書館だより $25,2013,8$ 頁。

23）京都帝国大学文科大学地理学研究室の『明治41 昭 和11 備品出納簿』によると, 明治41年12月21日の買 入として，「具足1,360円，若林茂一郎納」と記録され ている。続けて, 翌年 1 月 21 日の払出として, 「瑞典 國へデイン博士へ記念品トシテ贈與」と記されている。

24）前掲17）(1)。

25）前掲17）(1)。

26）陳列されたへディンの著書 7 点のうち，下記の 3 点 の内表紙にへディンの署名がある。いずれも現在は, 
文学研究科図書館所蔵。(1)Hedin, S., Central Asia and Tibet: towards the holy city of Lassa, 2 vols, Hurst and Blackett, 1903 (署名されているのは第 1 巻), (2) Hedin, S., Adventures in Tibet, Hurst and Blackett, 1904, (3) Hedin, S., Scientific results of a journey in Central Asia and Tibet 1899-1902, 3 vols, Lithographic Institute of the General Staff of the Swedish Army, 1904 (署名されているのは第 1 巻)。

27）前掲19）110頁。

28）前掲17）（1）。

29）前掲17）（1）b6-b7頁。

30）前掲 4 ） 191頁。

31）関西美術院『関西美術院院内日誌』（京都府立総合 資料館編『京都府百年の資料 八 美術工芸編』京都 府，1972） $1 \sim 27$ 頁。明治39年 3 月 2 日の開院式挙行 から明治44年12月14日までの日誌を収録。日誌の主な 内容は, 院長はじめとする教師の来院, 生徒の入院, 休学届, 講義, モデルの欠席等, 学務に関わることで, 日々の記録は 1 数行と簡潔。ヘディンの京都滞在期 間中（明治41年11月28日から12月12日）の日誌は, 12 月10日（文学士島文次郎氏講演）と同12日（書類 2 通 の処理と島文次郎への菓子折呈上) のみ。

32）（1前掲 4）191頁。(2)前掲 7 ) (4)3-6頁。

33）前掲16）(1)，(2)，および前掲17）(1）。

34）(1)大阪毎日新聞「大探検家 十四日来朝のヘヂン博 士 三回十五ケ年の大探検者」(1908年11月 1 日) で ヘディンの訪日予定を伝え，探検ならびに博士を紹介 （2 頁全面を割いた記事）したほか，東京帝国大学で の講話を連載（20回余り）している。また，11月29日 の紙面には，11月18日，招待された徳川侯爵家で贈ら れた扇の写真を掲載している。この扇子には，寺崎廣 業（日本画家，1866-1919）が中央アジアの山を描き, ヘディンは探検への夢をいだくきっかけとなったノル デンショルド（1832-1901）（極地方探検家）の誕生日 （招待された当日）と自署した。このエピソードは, ヘディンが探検人生のなかで，常に彼を励ましてくれ たノルデンショルドを意識していたことをうかがわせ る。(2)大阪朝日新聞「へデイン博士（東京を出発して 京都へ向かう)」（1908年11月28日）を伝えたほか, 「(12月) 2 日のへ博士」「 3 日のへ博士」など連日， ヘディンの動静を報道。(3)京都日日新聞「探検家へデ イン氏」（1908年11月10日）の記事で訪日（東京, 京 都）の予定を告げ, 「京城電報（十四日發）へヂン博 士 昨夜 連絡汽船にて来着せり」(1908年12月15日) に至るまで, 京都市内でのへディンの行動を詳しく掲 載。

35）前掲17）(5)129-130頁。

36）前掲17）(5)321頁。

37）前掲20)。

38）田中薰「東京地学協会と父と私」地学雑誌78, 1969, 202頁。田中薰の父, 田中阿歌麿は, 東京地学協会の ヘディン接待掛の一員であった（前掲16）(2) a6頁)。

39）松方三郎「B君の話など」(ヘディン中央アジア探 検紀行全集 第11巻）月報11，1966，1-3頁。

40）前掲11）(2)。

41）前掲17）(2)。
42）延岡繁「日本におけるスヴェン・ヘディン」人文学 部研究論集 (中部大学) 1，1999，117-126頁。

43）前揭10)。

44）(1)龍谷大学龍谷ミュージアム・読売新聞社編『特別 展 仏教の来た道一シルクロード探検の旅』龍谷大学 龍谷ミュージアム・読売新聞社，2012。図録には，大 谷家別荘でのへディンを交えた集合写真（1908年12月 3 日あるいは10日に撮影）やへディンと大谷家および 大谷探検隊との関わりが記載されている (166頁)。同 展には, ヘディン歓迎行事に尽力し, 出迎えや見送り の旅程も共にした堀賢雄の日記が展示されているが, 1908年当時のものはない (164頁)。同展の会期は, 2012年 4 月 28 日～ 7 月 16 日。(2)龍谷大学龍谷ミュージ アム・和田秀寿編『特別展 二楽荘と大谷探検隊：シ ルクロード研究の原点と隊員たちの思い』龍谷大学龍 谷ミュージアム・京都新聞社・神戸新聞社, 2014。同 展の会期は，2014年10月 4 日〜 11月30日。

45）前掲17）(5)139頁。

46）前掲17）(5)139-143頁。

47）大阪毎日新聞「国民教育に及ぼせるへヂン博士の来 朝 志賀重昂氏談」(1908年11月29日)。

48）（1前掲16）(2) a14頁によると，ヘディンは，東京地 学協会の歓迎式典での答辞のなかで, 中央アジアおよ びチベットに入った日本人として, 大谷 (光瑞) 伯爵, 成田安輝, 河口慧海を挙げ, 彼らの学術的な功績をた たえている。(2)金子民雄「光瑞とへディンの交流」 (前掲10)，第 1 章，70-88頁)。(3)ヘディンはTransHimalaya の第 3 巻 (1913)，第19章で, 河口慧海の 1897から1903年にかけてのインドとチベット旅行を取 り上げ，慧海の貴重な観察を褒める一方で，彼のたど つた経路の記載を地理学的な観点から批判している (227-231頁)。同書には，慧海のチベット旅行記とし て Handbook of Tibet (1904) が挙げられているが, 英訳版 (Three years in Tibet) がイギリスで刊行さ れたのは1909年であった。(4)Hedin, S., Southern Tibet: discoveries in former times compared with my own researches in 1906-1908, vol. 1 9, Lithographic Institute of the General Staff of the Swedish Army, 1917-1922のなかの第 2 巻 (1917) では, 第17章（pp. 114-122）と第35章（pp. 238-242）に, Kawaguchi というタイトルを付け，南チベットの慧 海の探検とヤルツァンポ川（Tshanpo, ブラマプトラ 川）の源流の検討に関して，慧海を取り上げている。 橘瑞兆と大谷伯爵の名前は, カラコルム探検史を論述 した第 7 巻（1922）に登場する（p. 415）。また，金 子民雄『へディン研究』新生文化社，1969，11頁によ ると，本願寺に宿泊したおり，ヘディンが楼蘭の正確 な位置を大谷光瑞に伝え，大谷が直ちにその情報を卜 ルファンに滞在していた橘瑞超に打電し（12月13日）, そのことが，楼蘭での「柏李文書」発見につながった。

49）前掲48）(4)の第 1 巻（1917）の第 12 章（pp. 114122）で, ヘディンは，ブラマプトラ川とサトレジ川 についての，「Shui-tao-ti-Kang」(齊召南編録『水道 提綱』, 清代, 乾隆年間に作成, 全 28 巻) 第 22 巻の記 述をもとに論じている。この記述内容 (pp. 114-116) は，1908年の京都滞在中に，小川环治が英語に翻訳し たものをそのまま用いている。『水道提綱』は,ヘデ 


\title{
A Preliminary Observation of the Drawings and Paintings Related to Sven Hedin Stored at Kyoto University: A Legacy of His Stay in Japan in 1908
}

\author{
TANAKA Kazuko \\ Kyoto University
}

Sixty works of reproduced drawings and paintings were recently found in the Department of Geography, Faculty of Letters, Kyoto University. They were drawn and painted with pencil, pen, or watercolor. On some of the works, short alphabetical notes include Tibetan place names and comments in Swedish. A preliminary observation of these works made clear that: (1) Four young art students made the reproductions. (2) They made copies from Sven Hedin's original works drawn and painted in Tibet during his explorations in Central Asia (1905-1908). (3) The reproductions vividly depict mountains, lakes, Tibetan temples and monks, ethnic costumes and people of Tibet, etc. They are artistically very excellent. (4) After his explorations, accepting the invitation of the Tokyo Geographical Society, Hedin visited Japan for one month at the end of 1908. Hedin stayed in Kyoto from November 28 to December 12. (5) At the time when Hedin delivered a lecture at Kyoto Imperial University on November 29, 108 sheets of his original paintings, drawings, and maps were exhibited in an adjacent room. It is conjectured that the four art students may have reproduced some of the exhibited paintings and drawings in less than two weeks before Hedin left Japan.

This observation indicates that the reproduced works found at Kyoto University are evidence of international academic exchanges in modern Japan. Hedin was welcomed by people in many disciplines, and they had intellectual and cultural discussions. The reproduced works are also very important visual materials showing the Tibetan landscape and culture of about one hundred years ago, because field surveys by foreigners had been severely restricted or forbidden in Tibet for centuries. These sixty reproductions are extremely valuable as research objects for the study of the modern histories of geography, ethnography, Sinology, Tibetan studies, the arts, and their disciplinary interactions.

Key words: Sven Hedin, drawings and paintings, reproduced works, Tibet, Kyoto, modern Japan 